$\begin{array}{rrr}\text { O片平 清昭 須田 } & \text { 耕吉 } \\ \text { 永井宏 塚原 進 } \\ \text { (福島県立医科大学 ) }\end{array}$

1.はヒめに

VDT 作業PC R T 作亲には視党が最も密 接に関保している。しかし，視觉系を補助し

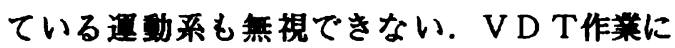
よる藉症状は”むち打ち症”と類似している。

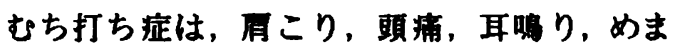
いや吐き気などの諸症状を呈するがここれら は主に頚部の異常に起因するものでもある.

本英联の目的はVD T作莱によるむち打ち 样症状の発現機楼を解明することである。そ こで，咬笳や頚部諸筋の筋田园，まばたき， 呼吸や G S Rなどの各種生体情報の同時記録 を行って，時间経渵にともなうそれらの变娌 状況について比較検討した。

\section{2. 实方法}

V D T 作莱は，パーソナルコンピュータの カラーデイスプレ (14付）画面上にアルフ ナベットのA，B，C，D，Eの中から等作為に 5 個を 1 行に粶色で表示して，最初の文字と 同じものが戌り 4 個の中に何個あるかを模索 してキーボード上の数字で答えるというもの である.被䮲者にはこの作童を 120 分间連 榬して䐂した，作菜奻事をみるために，5分 ことに模索数と俱り数（エラー数）を算出し た. 被騂者は23〜40才の煡䐂な成人男性 8名てある。

生体情報として、まばたき，呼吸，GSR

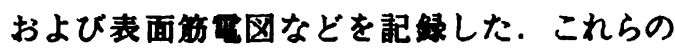
生体情報の記録は，作菜前（5 分以上の安祢 状意），VDT作亲中，作羓後（5 分以上の 安静状意）について連哱的に行って 1 分こと
に処理した．まばたきは上下の眼瞼から西気 的に算出し，呼吸は道に㨉入したサーミス タによって模出した．GS Rは通西法により 足底前部から記録した，管電园の学出部位は 右上顆の咬筋部，右胸鎖叱突筋の中央部，左 右僧帽筋の上部（到の後背部），右僧馆箭下 部（同部）および右前愁の榑指伸筋である. 記録した筋雪罒は，便宜上，パソコンの夕フ レット上で 1 分間ごとに記録波形をトレース しその面䅡を求めて放雪昷とした.

\section{3. 枯果}

被㙂者によって個人差はあるが，VDT作 羍の网始とともに，まばたき頪度は著しく娍 少し，作菜後には，作㷣前のレベルかそれ以 上に增加していた，呼吸数は作業後半に一時 的に変化するものの全体としての大きな変動 はみられなかった。

図1はある被臨者による桔果の1例である。 一番上の四には，VDT作羓時の5分ごとの 検索数とエラー数を示し，その下の四は，上

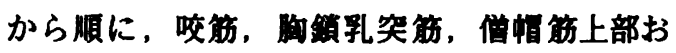

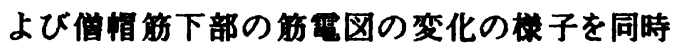
に示した、模索数とエラー数はともに作菜開 始後 $30 \sim 40$ 分後まで次第に增加し，その 後、それぞれ，170〜180，20〜30 程度で推程した。

筋西图は，いずれの部位でも放正の增娍 を梠り返しながら全体として稌々に增加する

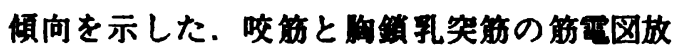
刃は作菜の後半での增加が顥著であった．ま た，僧情筋下部では，作美网始時と 90 分後 
付近で著しい筋四目放䖪が 認められた。作菜前と比䩪 して，作羓後には，咬笳， 胸銷乳突筋および僧帽筋上

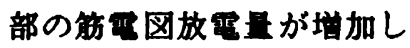
ていた．被䮲者の行動との 対応では，画面表示の変わ る時などに，垂浓を歕み込 んたりり奥歯を畋む娌作によ って咬笳筋電図の放電がみ られた。

\section{4.まとめ}

延能，橋および中销を含

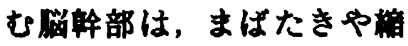
睦，眼球運動などと密接に 阅保しており，姿悬や平衡 に并わる反射中权もある。 また，政幹からでる副神柽

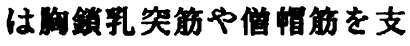
既している。したがって， 上の枯果のように, VDT 作羍によって頚部の諸筋の 策張が長時间持楼する所見 は局こりやむち打ち桹症状 の愁新の重要な背景になる と孝えられる。

目 1

VD T作羓時の作羓奻事

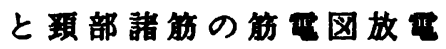
是の柽遇 一番上の四が梖案数とエラー数を示す

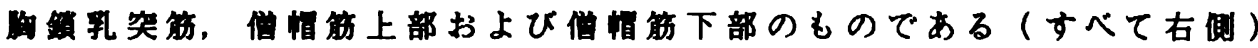

作莱後
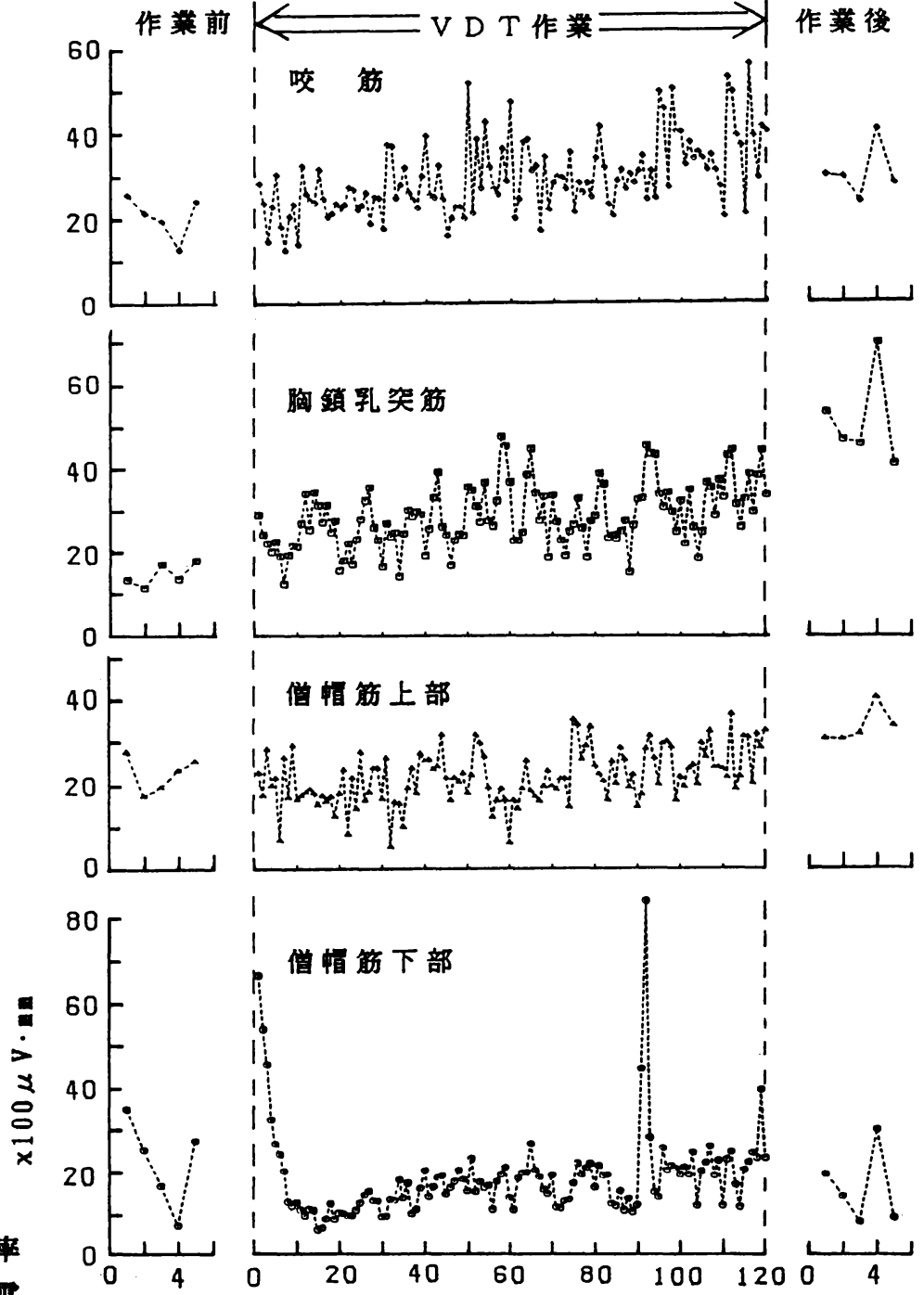

）僧帽筇上部

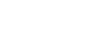

時间 (分)

检窈数

エラー数

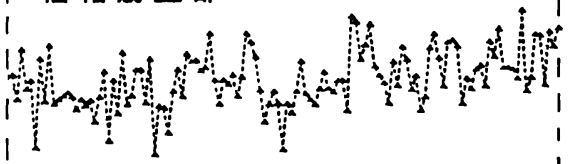

